\title{
Revealing Students Attitudes (Views and Assessments) on Drug Use in Vocational High Schools in Padang
}

\author{
Rahmi Izzati ${ }^{1}$, Firman ${ }^{2}$, Yanuar Kiram ${ }^{3}$ \\ ${ }^{123}$ Guidance and CounselingUniversitas Negeri Padang \\ *Corresponding author, e-mail: rahmiizzati28@gmail.com
}

\begin{abstract}
Drug abuse one of the problems that have swept the world and become a frightening problem for the society and Indonesian. Students become one of the targets of drug abuse. Drug abuse occurs during adolescence because adolescents have rapid biological, psychological, and social changes that cause vulnerable individuals to get involved in drug abuse. The cause of drug abuse among adolescents was due to the low attitude of students in addressing the occurrence of drug abuse. The population of this research was the students of SMK in Padang. There were 124 students as the sample of this research. The sampling technique used was a purposive random sampling and the data collection tools used student attitude instruments used students' attitude instruments in drug abuse with a Likert scale model, with Alpha Cronbach reliability of $\mathrm{r}=0,991$. The data were analyzed by using the descriptive statistical methods with the data processing using SPSS version 22. The results revealed that the students' attitudes in drug abuse were in the middle category $(54.2 \%)$. Clearly, the affective component was in the middle category $(2.69 \%)$; the behavioral component was in the middle category $(2.91 \%)$; the cognitive component was in the low category $(2.47 \%)$.
\end{abstract}

Keywords: Drug Abuse, Attitude.

How to Cite: Izzati, R., Firman, F., Kiram, Y. (2020). Revealing Students Attitudes (Views and Assessments) on Drug Use in Vocational High Schools in Padang. International Journal of Applied Counseling and Social Sciences. 2 (2): pp. 76-81, DOI: 10.24036/005362ijaccs

\section{Introduction}

The World Drug Report 2017 states that around 255 million people in the world aged 1564 are drug abusers with an estimated global death of 207,400 people per year (UNODC, 2017). BNN and Putlikes UI survey results found that the number of drug abuse in Indonesia has increased every year. In 2009 to 2011 , there were $1.99 \%$ of the population, $2.21 \%$ of the 
population and $2.25 \%$ of the population (Faridah \& Atakari, 2018). The data from the BNN and Putlikes UI in 2017 explained that in the 10-59 years age group there were drug abuse as many as $1.77 \%$ or equivalent to $3,376,115$ people and 11,071 people died every year or 30 people died every day (Republic of indonesia national Narcotics Agency (BNN) and University of Indonesia Health Research Center (Putlikes UI)., 2017)

Based on data from the Provincial National Narcotics Agency (BNNP) in 2018, it shows that the province of West Sumatra ranks 23 drug users from 34 provinces in Indonesia. From the total population of West Sumatra aged 10-59 year which is $3,664,900$ people, there are 63,352 people affected by drugs. The category of workers reached 22,174 people, 20,906 students and 20,272 people were unemployed and housewives (Amalianita \& Firman, 2019).

West Sumatra Provincial Narcotics Agency (BNNP) Rehabilitation Data in 2018 revealed that drug abuse cases of students in West Sumatra were 135 students at primary school level, 209 students at junior high school, while at 373 high schools / vocational high schools where at $45 \%$ of high schools or 167 students and at SMK as many as $55 \%$ or 206 drug abusers, in this case at the Vocational High School level is the most drug abuse case from the existing educational level (Amalianita \& Firman, 2019). West Sumatra Provincial Narcotics Agency (BNNP) Rehabilitation Data in 2018 shows that drug abuse among students in West Sumatra is 135 students at the elementary level, 209 students at SMP, while at 373 students at SMA / SMK, where at 45 percent at SMA or 167 students and at SMK as many as 55\% or 206 students abuse drugs (Amalianita \& Firman, 2019). In this case at the Vocational High School level is the most drug abuse cases from the existing education level.

Based on available data, it can be understood that one of the targets that become victims of drug abuse is students. Where students are at the level of secondary education, the period of secondary school (SMA) is equivalent to coincide with adolescence. During adolescence, an individual experiences a development process, where development is a progressive and continuous change that occurs in an individual from birth to death (Joseph, 2014). Adolescence (adolescence) is a period of development which is a transition period from children to adulthood, based on age, this period starts around the age of 10 years to 12 years and ends at the age of 18 years to 21 years (King, 2012).

Drug abuse occurs during adolescence because adolescents have rapid biological, psychological, and social changes that cause vulnerable individuals to abuse drugs (Taringan, 2017). A great curiosity combined with a desire to try new things, an attitude of not afraid to take risks, a tendency to act without careful consideration, easily dissolve in the flow of relationships, and think short, all of which put teens in vulnerable positions (Muhajir, 2007).

One of the causes of the spread of drug abuse in adolescentsis because of the adolescents' attitudes towards drug abuse. Orbell's research results (Trisakti \& Astuti, 2014) suggest that the attitude of a adolescent from the beginning will determine the subject's tendency to use or not use drugs. Adolescentstend to be curious so that they will seek information about drugs. Therefore, by getting that information, adolescents can form attitudes and behaviors that avoid drug abuse. However, it can also be with the attitude of wanting to find various sources of information about adolescent drugs, adolescents will tend to have the potential to use drugs, for example, starting with just trial and error (Asti et al., 2014). 
Sarwono (Ratnasari, 2015), revealed that one of the factors causing drug abuse is the students' attitudes in dealing with drug abuse. Many factors can cause adolescents to start abusing drugs, so that it can eventually lead to dependency. Some of the factors that cause drug abuse include individual factors, environmental factors (family environment, school, and peers), education factors (knowledge and attitudes) and drug availability factors (Andika, 2017).

Orbeli research results (Andika, 2017), revealed that the attitude of adolescent from the beginning will determine the subject's tendency to use or not use drugs, adolescents are expected to have a positive attitude towards the prevention of drug abuse. Waluyo (Andika, 2017)revealed that to prevent these adverse effects, efforts to prevent drug abuse are needed. Efforts to prevent drug abuse include primary, secondary and tertiary prevention. Prevention of drug abuse can be done with communication, information and education activities, so adolescents need knowledge and attitudes about drugs so that adolescents can protect themselves from various drug problems.

Blackwell (Faisal, 2019)argues that attitude is a form of evaluation of certain behaviors that involve the object of attitude. Attitude is an important part of predicting and explaining human behavior, Ajzen (Faisal, 2019). Attitude is a reaction or response of someone who appears to an object which then raises individual behavior towards the object in certain ways (Lestari \& Pramono, 2020). Attitude is a reaction that arises as a result of receiving a stimulus (Lestari \& Pramono, 2020). Schiffman, Kanuk \& Hansen (Lestari \& Pramono, 2020)suggested that there are three components of attitude that influence each other, namely the cognitive component, the affective component and the conative component.

Looking at the problems that occur in adolescents, schools have an important role to prepare students to achieve success in the future, namely by developing personal, social, learning and career. Institutionally guidance and counseling is part of the overall education program in schools, which is designated to help or facilitate students to achieve development tasks optimally (Nengsih et al., 2015). Achieving this is certainly inseparable from the efforts and cooperation of all school personnel.

Therefore, it is necessary to conduct a study as a first step to determine the condition of students' attitudes in drug abuse in the Vocational School of Padang. This is done because one factor is the occurrence of drug abuse due to the low attitude of students in drug abuse. Furthermore, this research can be used as a basis for counselor in carrying out guidance and counseling services in schools, especially in the prevention and alleviation of drug abuse problems.

\section{Method}

This research use a quantitative method that was descriptive in order to answer research questions. A descriptive quantitative research aims to explain the phenomena that exist by using numbers to describe the characteristics of individuals or groups (Syamsuddin \& Damiyanti, 2010). Sugiyono (2018)stated that quantitative methods can be interpreted as a research method based on the philosophy of positivism, used to examine a particular population or sample, data collection using research instruments, quantitative/statistical data analysis, with the aim to describe and test hypotheses that have been set. The targets in this research were the students of Vocational High Schools In Padang which 
were SMK Negeri 1 Sumatera Barat and SMKS Muhammadiyah 1 Padang. The stages of the research began by establishing the sample of the research through observation and interviews with the counseling teacher. The research sample was 124 students. The sampling technique used purposive random sampling with the data collection tools in the form of Social Adjustment Scale (SPSS). Data collection tools use the attitude instrument of students in drug abuse with a Likert scale model, with Alpha Cronbach reliability of $r=0,991$. Data were analyzed using descriptive statistical methods with data processing using SPSS Version 22.

\section{Results and Discussion}

Based on data analysis that has been done regarding the condition of the students' attitudes in Drug Abuse in Vocational High Schools in Padang, the following explanation was obtained.

Table 1.The Description of the Mean (\%) and Percentage (\%) of Students' Attitudes in Drug Abuse based on Sub-variabless.

\begin{tabular}{|l|l|c|c|c|c|c|}
\hline \multirow{2}{*}{ No } & \multicolumn{1}{|c|}{ Sub-Variables } & \multicolumn{5}{c|}{ Score } \\
\cline { 3 - 7 } & & Ideal & Max & Min & Mean & Sd \\
\hline 1 & Affective component & 60 & 50 & 23 & 32,28 & 5,05 \\
\hline 2 & Behavioral component & 110 & 103 & 42 & 63,95 & 10,63 \\
\hline 3 & Cognitive component & 85 & 72 & 32 & 42,61 & 7,63 \\
\hline \multicolumn{2}{|l}{ Total } & $\mathbf{2 5 5}$ & $\mathbf{2 2 0}$ & $\mathbf{1 1 0}$ & $\mathbf{1 3 8 , 8 5}$ & $\mathbf{2 1 , 0 0}$ \\
\hline
\end{tabular}

Information:

Max:Highest Score obtained by Students

Min:Lowest Score obtained by Students

\section{Sd:Standard Deviation \\ $\mathrm{R}:$ Low}

Table 1 above explains the overall students' attitudes in drug abuse with an ideal score which was 255. The highest score obtained by the students was 220, and the lowest score obtained by the students was 110 . Then, the average score obtained by the students that was 138.85 and the standard deviation was 21.00.

Table 2. The Students' Attitudes in Drug Abuse ( $n=124$ students)

\begin{tabular}{|c|c|c|c|c|c|}
\hline \multicolumn{6}{|c|}{ The Total of Students' Attitudes in Drug Abuse } \\
\hline \multicolumn{2}{|c|}{ Classification } & Frequency & Percentage & Valid & Cumulative \\
\hline \multirow{6}{*}{ Valid } & Very & 2 & 1,6 & 1,6 & 1,6 \\
\hline & High & & & & \\
\hline & High & 15 & 12,1 & 12,1 & 13,7 \\
\hline & Middle & 21 & 16,9 & 16,9 & 30,6 \\
\hline & Low & 86 & 69,4 & 69,4 & 100,0 \\
\hline & Total & 140 & 100,0 & 100.0 & \\
\hline
\end{tabular}

Table 2 above summarizes the overall students' attitudes in drug abuse that was 124 students. There were 86 students in the low category (69.4\%) with a validity of 69.4 percent and a cumulative percentage of 100.0, while in the middle category there were 21 students 
(16.9\%) percentages with legal percentages 16.9 and cumulative percentages 30.6 , in the high category there were 15 students (12.1) with legal percentages 12.1 and cumulative percentages 13.7 and in the very high category there were 2 students $(1.6 \%)$ with a valid percent of 1.6 and cumulative percent of 1.6. Thus, it can be concluded that the students' attitudes in drug abuse are generally in the low category (69.4\%). This condition needs to be improved and does the follow up.

\section{Conclusion}

Based on the results of the research, it revealed that the condition of students' attitudes in drug abuse was in the middle category (54.2\%). There were 2 students in the very high category $(1.6 \%)$. In the high category there were 15 students $(12.1 \%)$. In the middle category there were 21 students (16.9). In the low category there were 86 students $(69.4 \%)$, and in the very low category there was no student $(0 \%)$. Meanwhile, the affective component was in the middle category $(2.69 \%)$; the behavioral component was in the middle category $(2.91 \%)$; the cognitive component was in the low category $(2.47 \%)$. This needs to be improved again with follow-up. This condition needs to be a concern for BK/Counselor teachers as professionals through guidance and counseling services in schools to help the students have a positive attitude as a basis for the elf-prevention from drug abuse.

\section{References}

Amalianita, B., \& Firman. (2019). The effectiveness of group guidance in increasing the students assertiveness on prevent drug abuse Pendahuluan. Jurnal Aplikasi IPTEK Indonesia, 3(2), 58-65.

Andika, M. (2017). Hubungan pengetahuan dan sikap remaja dengan upaya pencegahan penyalahgunaan narkoba di SMPN 29 Padang tahun 2017. Jurnal Kesehatan Prima Nusantara Bukittinggi, 9(2), 100-108.

Asti, Y., Fitriangga, A., \& Handoko, W. (2014). Hubungan pengetahuan dan sikap terhadap perilaku penyalahgunaan narkoba pada siswa/i SMP Negeri 4 Kecamatan Pontianak Timur.

Faisal, M. (2019). Sikap, norma subjektif, religiusitas, dan partisipasi terhadap wakaf tunai. $L i$ Falah, 4(1), 235-250.

Faridah, \& Atakari, E. R. (2018). Hubungan pola asuh orangtua dengan penggunaan narkotika, psikotropika dan zat adiktif lainnya (NAPZA) pada remaja. Jurnal Kebidanan, 8(November), 138-142.

King, L. A. (2012). General psychology is an appreciative view. Salemba Humanika.

Lestari, A. D. A., \& Pramono, A. (2020). Pengaruh psikoedukasi pencegahan penyalahgunaan narkoba terhadap komponen sikap pada siswa SMP. Journal of Community Medicine,8(1), 1-7.

Muhajir. (2007). Sports and health physical education for high school class X. Erlangga.

Nengsih, Firman, \& Iswari, M. (2015). Pengaruh layanan bimbingan kelompok terhadap perencanaan arah karier siswa SMA pembangunan laboratorium Universitas Negeri Padang. Konselor, 4(3), 136-146.

Ratnasari, Y. (2015). Hubungan pengetahuan, sikap siswa tentang bahaya narkoba dan peran keluarga terhadap upaya pencegahan narkoba. J. Kesehat. Masy. Indones., 10(2). 
Republic of indonesia national Narcotics Agency (BNN) and University of Indonesia Health Research Center (Putlikes UI). (2017). Penyalahgunaan narkoba.

Sugiyono. (2018). Quantitative research methods. Alfabeta.

Syamsuddin, \& Damiyanti. (2010). Language education research methods. Rosdakarya.

Taringan, I. J. (2017). The role of the national narcotics agency with social organizations in the handling of narcotics abuse offenders. Deepublish. Yogyakarta. UNODC. World Drug Report 2017. UNITED NATIONS.

Trisakti, \& Astuti, K. (2014). Hubungan antara harga diri dan persepsi pola asuh orang tua yang authoritatif dengan sikap remaja terhadap penyalahgunaan narkoba. Jurnal Ilmiah Guru "COPE,"2.

UNODC. World Drug Report 2017. New York: UNITED NATIONS. 